УДК 528:631.616

ББК 40.64

\title{
THEORY OF GEOINFORMATIC MAPPING OF EROSIVE GEOMORPHOLOGICAL SYSTEMS
}

\author{
Aleksandr Sergeevich Rulev \\ Doctor of Agricultural Sciences, Corresponding Member of RAS, \\ Deputy Director for Science, \\ All-Russian Research Institute of Agroforest Reclamation \\ rulev54@rambler.ru \\ Prosp. Universitetsky, 97, 400062 Volgograd, Russian Federation \\ Valeriy Grigoryevich Yuferev \\ Doctor of Agricultural Sciences, Professor, Chief Researcher, \\ All-Russian Research Institute of Agroforest Reclamation \\ vyuferev1@rambler.ru \\ Prosp. Universitetsky, 97, 400062 Volgograd, Russian Federation
}

\begin{abstract}
The geoinformatic mapping of erosion geomorphologic systems is based on both traditional methods of cartographic representation of information and specific opportunities of computer mapping complexes, including those for analytical processing of data of different types. The study of the characteristics of the erosion geomorphological systems is carried out with the use of aerial and satellite imagery and is based on the results of their geomorphological, geobotanical, soil reclamation, erosion and other surveys. Spatially distributed input data of landscape model should be set as raster electronic maps that characterize relief, soil cover, type of agriculture, vegetation on the catchment area, as well as, morphometry and hydraulic resistance of the channel and floodplain, and also as a set of the attributes describing their characteristics. The use of digital model of relief (DMR) while geoinformatic mapping provides the determination of both planning characteristics of the relief and profile ones, including the values of slope angles, inclination, expositions, slopes configuration, etc. As the result of the modelling, the digital maps of flow, outwash and accumulation, and table data defining the process of flow, outwash and water turbidity, as well as, their final values with the use of large-scale topographic and soil maps, and space imaging of high resolution, are developed.

Key words: theory, geoinformatic, mapping, erosion, geomorphology, landscape, model, degradation, outwash, space images.
\end{abstract}

The theoretical substantiation of the methods of study of the structure, state and dynamics of degradation processes is based on the optics laws. The light reflection of natural objects [4] while processes of relief transformation analysis has its own logics and is described by the laws of optics. The study of the characteristics of specific landscape objects reflection, development of photo standards catalogue, analysis of reflected light spectrum and obtaining of empiric mathematic dependences for description of geomorphologic processes - these are the problems developed by fundamental research.

The determination of erosion-geomorphologic systems from the point of view of erosion degradation is an important element of their 
management. In this connection, the task of scientific basing of erosion degradation mapping and zoning of its area according to its levels is an important research problem that is developed by the methods of attended analysis of the digital model of relief (DMR), large-scale topographic mapping basis and space imaging of the studied area, and additional information from field research, etc.

The mapping geoinformatic insuring becomes the priority at present time, including that for development of erosion-control measures. The insufficient insuring should be supplied by the development of special purpose geographical information system (GIS) as a basis for landscape analysis and development of necessary subject layers of digital computer mapping models. One of the most important sources of information on landscapes and their state are the results of remote sensing - optical, lidar and radar surface images.

The landscapes are analysed with the use of aero and space imagery according to the results of their geomorphologic, geobotanic, soil ameliorative, erosion and other inspections. The methodical bases for said inspections are given in the papers of N.N. Bobrovitskaya, A.S. Rulev, V.G. Yuferev $[2 ; 6 ; 8 ; 9 ; 11 ; 18 ; 28]$.

The landscape mapping provides the development of maps serial that characterizes the natural potential of the studied area, its ecological conditions, and current state of nature territorial complexes. The mapping process with the use of remote imagery of landscapes surface differs essentially from the traditional one used by usual subject mapping. Such difference consists in the significant exceeding of camera imaging in comparison with field research.

The papers of N.F. Glasovsky, A.S. Rulev, V.G. Yuferev and others $[5 ; 6 ; 7 ; 15]$ present the modern methods of erosion processes mapping on the basis of wide use of mathematical modelling of outwash. The development of input spatial distributed data and spatial presentation of modelling results leans upon the current opportunities of geoinformation technologies.

The input spatial distributed data of landscape model is set as raster electronic maps characterizing relief, soil cover, type of land use, vegetation of watershed area, as well as, morphometry and hydraulic resistance of the channel and flood-plain. The modelling results in the development of digital maps of flow, outwash and accumulation, and table data showing the processes of flow, outwash, water turbidity, and their final values, with the use of large-scale topographic and soil maps, and space imagery of high resolution from satellites GeoEye, Quickbird, and others [24-27; 29].

The computer mapping provides the development of large set of tasks while landscapes modelling and study:

- definition of co-ordinates of site points;

- definition of site area;

- 3-D modelling of site relief, etc.

Such an approach corresponds to the direction developed for mapping and modelling of erosion degradation in the landscapes of southern Volga Upland.

At present, the space digital scan imaging doesn't have alternative in such aspects as covering, recurrence, and regularity, as for the resolution, it approximates to the analog aerial photography. A new informational medium is being developed on the basis of the available archives and actual space images that is capable of continuous monitoring of the chosen research objects. It being necessary to develop the methods of information analysis and required mapping layers with subsequent technologies of landscapes mapping with the help of Geographical Information Systems.

GIS - are the information systems providing collection, safety, processing, reflection, and dissemination of the data, and thus, the receipt of a new information and knowledge on spatialcoordinated objects and phenomena [1].

The distinctive feature of GIS is the spatial attachment of the information that provides landscape analysis. The information is presented as electronic maps with added datasets providing analysis and further development of new maps.

The main feature of the electronic maps in Geographical Information Systems is that they represent not ordinary static pictures. Each conventional sign in GIS corresponds to some object that can be analysed to get exhaustive additional (non-graphic) information from the datasets. Therefore, one of the basic functions of GIS is the receipt of information on the chosen mapping object.

The use of mapping as a data source is effective due to the several reasons. First, the attributive characteristics obtained from mapping sources possess territorial attachment, second, 
there are no blanks within the limits of presented space in them, third, there is a lot of effective technologies to digitize said materials.

One of the main informative sources for GIS are the materials of remote sensing unifying all data types from satellites and aerial platforms.

Today, the space imaging provides the operative, reliable and qualitative monitoring of forest reclamation objects, while the opportunity to flow repeated images of the same territory shows the spatial-temporal dynamics of proceeding processes. The technologies based on photography and scan space systems are the most acceptable for landscape monitoring [12; 13; 30]. Thus, the optical and scanning devices working in the diapason of reflected solar radiation, including ultra-violet, visible and near infrared diapasons that provide high resolution and geometric precision are being used.

The present space satellites are characterized by different orbital parameters and opportunities of imagery sensors [23-27;29] that condition the spheres for generated satellite images application.

To decipher the objects with linear parameter over $10 \mathrm{~m}$, the images from satellites Landsat- 8 or Spot- 5 and others should be used. The majority of satellites orbits provide the repeated imagery every 1-5 days, thus giving the opportunity for rapid processes monitoring. The radio- and geometric characteristics of images from different satellites assume different approaches for their instrumental and computer deciphering. Therefore, there is a large option of computer programs with various functional opportunities. The use of such programs, as ENVI, MapInfo, Surfer, "Talka" develops various tasks in processing and analysis of space images: visualization, geometric and brightness correction of digital images, attachment and classification (automatized deciphering) of space images, construction of locality profiles, digital modelling of relief and landscape (DML) creation of isolinear and thematic maps, development of datasets and corresponding thematic tasks, etc. $[16 ; 19 ; 20]$.

Lately, the global positioning systems (GPS, GLONASS) correcting the co-ordinates of geographical information models with the precision of several metres to several millimeters have being widely used.

Digitized statistic materials are convenient for direct use in GIS, as well as, for analysis and calculation of necessary data. As a rule, it's not one type data, but a combination of different data concerning to some territory.

GIS disposes of special functions, such as digital modelling as a method of representation, safety and driving of data in the aspect of digital signals in computer systems. The theoretical basis of computer landscape modelling was considered in the papers of Ye.A. Garshinev, A.S. Rulev, V.G. Yuferev, A.M. Trofimov and others $[3 ; 9 ; 10 ; 14$; $16 ; 21 ; 22]$.

The dataset necessary to describe landscapes forms a positional field, including topologygeometric and attributive data. The erosion geomorphologic systems as an object for information modelling (digital description) are various and classified to the spatial location of their objects.

The digital description of a landscape includes its name, location, main characteristics, topologic features, relationship with other objects. The name of the landscape is its geographic name, conditional code given by the user or the system. Its location is defined by co-ordinates that set the geographical position of the landscape. Those features represent the geometric component of the data description that is different from its nonpositional properties.

The characteristics are determined by the qualitative and quantitative landscape attributes that match its digitized data. They can be generated while data processing or automatically by the system (such as, co-ordinates, the values of the areas and perimeters of polygon objects).

The attributes are the content, thematic (nonpositional, non-spatial) properties. The topologic properties are such properties of a spatial object, as a dimension, isolation, connectivity, location on the boundary, inside or outside the polygon.

The total dataset representing a digital model of a landscape should be considered as three integral parts: topologic, geometric and attributive. In general, to describe one- and two-dimensional objects the models of two types - raster and vector - are used. The raster data model assumes a decomposition of the space into discrete indivisible elements (such as, pixels in computer graphics) arranged in a rectangular matrix. The vector models are used for digitizing of the point, line and polygonal objects.

GIS software usually support one, rarely two models of spatial data depending on the peculiarities 
of the developed problems and user demands being the main criteria for its choise.

To develop a multi-layered digital map the obtained layers should be transformated into a unified co-ordinate system. The co-ordinate system is connected with the mathematic basis of a traditional geographic map, geodetic framework, map projection, scale, co-ordinate grid, and layout elements.

The spatial images are attached to a geographic co-ordinate system by the characteristic points in the location (roads crossing, administrative boundaries, etc.). The geocoding is paid great attention in current GIS, consisting in objects attachment to the digital map of the territory, the spatial location of those is set with the datasheet. The information is presented by objects co-ordinates from receivers of GPS or GLONASS, digital addresses of the objects, etc.

One of the functions of GIS is a creation of a 3-D digital model of the relief, which is defined as a means of digital representation of 3-D spatial objects (surfaces) as 3-D data generating multiple height marks or other values of the applicate $(\mathrm{Z}$ co-ordinates) in the nodes of regular or irregular network [23].

The cartographic sources of scale $1: 500000$ and smaller are inppropriate generation of a digital model of the relief. The accuracy of DMR being one of the most important features of model quality should be estimated either by its compliance with the parameters (conditionally accepted as true) or by its relevance to the tasks developed in the process of the model utilization.

The digital raster and triangulation models of the relief are the most common ones. The raster model regarding the DMR indicates the matrix of heights, regular (usually square) network of height marks in its nodes, the distance between which (step) determines its spatial resolution.

The DMR of various types may be driven to a raster (matrix or regular) model by means of interpolation, approximation, smoothing or other transformation. To restore the height field in its any point (for example, in the node of a regular network) on given set of height marks (for example, on digital recording of contours) the various methods of interpolation (kriging, Shepard's method, etc.) are used.

The sources for generation of DMR are the data of geodetic and topographic imaging of the location, stereo photogrammetric processing of aero- and spatial images, actual GIS, radar analysis of the relief SRTM, ASTER GDEM, and systems of the global positioning. The digital modelling is based on the use of the two main groups of mathematic algorithms: the computation of height marks in arbitrary points on the initial set of irregularly spaced points or on initial points defined on the matrix of heights.

Consequently, the GIS mapping of erosion geomorphologic systems is based on both traditional methods of cartographic representation of the information and specific opportunities of computer mapping systems, that include the analytical processing of data of different kind. The peculiarity of electronic maps generated on the basis of spatial imagery of high resolution is their scalability up to the value of the resolution of the spatial initial image. The use of DMR when geoinformatic mapping provides the definition of the both planned features of the relief and profile ones, including values of slope angles, inclination, exposition, shape of the slope, etc.

\section{REFERENCES}

1. Berljant A.M. Mapping and Geoinformatics. Results of Science and Technics. Ser. Mapping. Moscow, VINITI Publ., 1991, vol. 14. 176 p.

2. Bobrovitskaya N.N. Systematic Recommendation on Use of Aero-Imagery Data for Analysis and Calculation of Soil Water Erosion Characteristics. Leningrad, Gidrometeo Publ, 1986. $110 \mathrm{p}$.

3. Garshinev E.A. Erosion Hydrological Process and Forest Reclamation: Theory and Models. Volgograd, VNIALMI Publ., 1999. 196 p.

4. Mikhaylova N.A., Orlov D.S. Optical Characteristics of Soil and Soil Component. Moscow, Nauka Publ., 1986. 120 p.

5. Glazovskiy N.F., ed. Estimation of Surroundings Quality and Ecological Mapping. Moscow, Izd-vo IGRAN, 1995. 213 p.

6. Proletkin I.V. History of the development of the relief and reconstruction of the river net of the Volga Upland and adjoining territories (Saratov State University). Available at: http://ogis.sgu.ru/ogis/ gis_otd/publ37.htm.

7. Rulev A.S., Juferev V.G. Aerocosmic mapping of erosion processes on the basis of catenarylogistical approach.. Zagorulko M.M., ed. Strezhen: scientific annual. Volgograd, Izdatel Publ., 2008, vol. 6, pp. 36-40. 
8. Rulev A.S. Landscape geographical approach in agroforest reclamation. Volgograd, VNIALMI, 2007. 160p.

9. Rulev A.S., Juferev V.G., Juferev M.V. Methodology of geographical information modelling. Herald of the Russian Academy of Agricultural Sciences. Moscow, 2011, no. 5, pp. 5-6.

10. Trofimov A.M., Moskovkin V.M. Mathematical modeling in slopes geomorphology. Kazan, Kazan university Publ., 1983. 219 p.

11. Juferev V.G. Remote sensing of the state and dynamics of agrolandscapes. Zemledelie Agriculture, 2007, no. 3, pp. 8-9.

12. Dicky E. Soil erosion: mechanisms and control. Mitchell Farm, Ranch and Houm Quarterli, 1984, vol. 30 (3a special), pp. 6-8.

13. Kulik K.N., RulevA.S., Juferev V.G. Aerospace monitoring of pastures in conditions of dry steppe and semi-desert. Abstracts of reports International Scientific Conference "Science, technique and innovation technologies in an epoch of great revival". Ashgabat, 2010, pp. 406-407.

14. Kulik K.N., Juferev V.G. Computer-Aided Mathematical Cartographic Modeling of Agroforestry Landscapes on the Basis of Aerospace Information. Russian Agricultural Sciences, 2010, vol. 36, no. 1, pp. 63-66.

15. Mapping and monitoring of the impact of gully erosion in southeastern Nigeria with satellite remote sensing and geographic information system. Available at: http://www.isprs.org/proceedings/ XXXVII/congress/8 pdf/9_WG-VIII-9/03.pdf/

16. Matheron G. Principles of geostatistics. Econom. Geol, 1963, vol.58, pp.1246-1266.

17. Raloff L. K. Soil Losses Eroding Food Security. Sci. News, 1984, vol. 126, no. 14, pp. 212.
18. Sakthivel R., Sakthivel R., Jawahar Raj N., Pugazhendi V. Remote Sensing and GIS for Soil Erosion Prone areas. Available at: http:// scholarsresearchlibrary.com/aasr-vol3-iss6/AASR2011-3-6-369-376.pdf.

19. Remote Sensing Science and Industry. Proceedings of the Remote Sensing Society, 1996, 715 p.

20. Rubec C.D.A. Applications of remote Sensing in ecological land survey in Canada. Canadian Journal of Remote Sensing, 1984, vol. 9, no. 1, pp. 19-30.

21. Rulev A.S., Yuferev V.G. The catena-logistical approach to the estimation and mapping of erosion processes on water catchment areas with the use of spaceaerophotos. Proceedings of the tenth International symposium on river sedimentation "Effects of river sediments and channel processes on social, economic and environmental safety". Moscow, 2007, pp. 348-355.

22. SPARTACUS: Spatial redistribution of radionuclides within catchments: development of GISbased models for decision support systems. EC Contract No. IC15-CT98-0215. Final Report. M. Van der Perk, Svetlitchnyi A. A., J. W. den Besten and A. Wielinga (eds). Utrecht Centre for Environmental and Landscape Dynamics Faculty of Geographical Sciences, Utrecht University, The Netherlands, 2000, $165 \mathrm{p}$.

23. http://www.sovzond.ru/satellites/

24. http://asterweb.jpl. nasa.gov/gdem.asp

25. http://dds.cr.usgs.gov

26. http://earthexplorer.usgs.gov

27. http://kosmosnimki.ru/

28. http://vega.smislab.ru/maps/fields.sht

29. http://www.geoeye.com

30. mcx.ru/documents/file_document/v7_show/ 19761.133.htm

\title{
ТЕОРИЯ ГЕОИНФОРМАЦИОННОГО КАРТОГРАФИРОВАНИЯ ЭРОЗИОННО-ГЕОМОРФОЛОГИЧЕСКИХ СИСТЕМ
}

\author{
Александр Сергеевич Рулев \\ Доктор сельскохозяйственных наук, член-корреспондент РАН, заместитель директора по науке, \\ Федеральное государственное бюджетное научное учреждение \\ «Всероссийский научно-исследовательский агролесомелиоративный институт» \\ rulev54@rambler.ru \\ просп. Университетский, 97, 400062 г. Волгоград, Российская Федерация
}

\section{Валерий Григорьевич Юферев}

Доктор сельскохозяйственных наук, профессор, главный научный сотрудник, Федеральное государственное бюджетное научное учреждение «Всероссийский научно-исследовательский агролесомелиоративный институт» vyuferev1@rambler.ru просп. Университетский, 97, 400062 г. Волгоград, Российская Федерация 
Аннотация. Геоинформационное картографирование эрозионно-геоморфологических систем базируется как на традиционных методах картографического представления информации, так и на специфических возможностях компьютерных картографических комплексов, включающих возможности аналитической обработки данных различного типа. Изучение характеристик эрозионно-геоморфологических систем проводится с использованием аэро- и космосъемки и основано на результатах их геоморфологического, геоботанического, почвенно-мелиоративного, эрозионного и других обследований. Входные пространственно-распределенные данные модели ландшафта задаются в виде растровых электронных карт, характеризующих рельеф, почвенный покров, характер землепользования, растительность на водосборе, а также морфометрию и гидравлические сопротивления русла и поймы, а также как совокупность атрибутов, описывающих их особенности. Использование цифровой модели рельефа (ЦМР) при геоинформационном картографировании обеспечивает определение как плановых характеристик рельефа, так и профильных, в т. ч. значений углов склона, уклонов, экспозиций, формы склонов и др. В результате моделирования создаются цифровые карты стока, смыва и аккумуляции, а также табличные данные, характеризующие ход стока, смыва, мутность воды и итоговые их величины с использованием крупномасштабных топографической и почвенной карт, а также космических снимков высокого разрешения.

Ключевые слова: теория, геоинформационный, картографирование, эрозия, геоморфология, ландшафт, модель, деградация, смыв, космические снимки. 